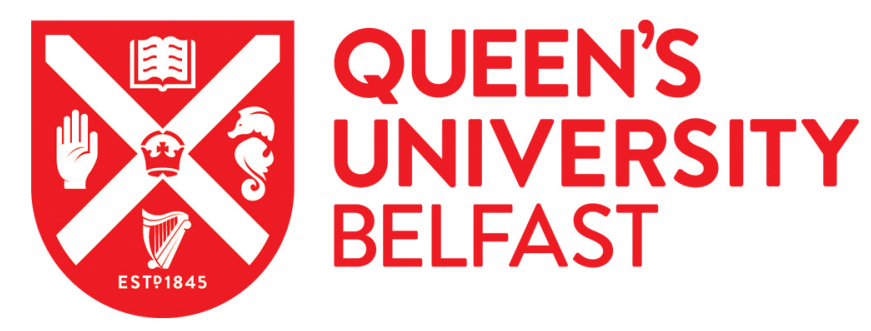

\title{
Public resource allocation, strategic behavior, and status quo bias in choice experiments
}

Silz Carson , K., Chilton, S., Hutchinson, W. G., \& Scarpa, R. (2019). Public resource allocation, strategic behavior, and status quo bias in choice experiments. Public Choice, 185, 1. https://doi.org/10.1007/s11127-01900735-y

\section{Published in:}

Public Choice

\section{Document Version:}

Peer reviewed version

Queen's University Belfast - Research Portal:

Link to publication record in Queen's University Belfast Research Portal

\section{Publisher rights}

(C) 2019 Springer Science+Business Media, LLC, part of Springer Nature.

This work is made available online in accordance with the publisher's policies. Please refer to any applicable terms of use of the publisher.

\section{General rights}

Copyright for the publications made accessible via the Queen's University Belfast Research Portal is retained by the author(s) and / or other copyright owners and it is a condition of accessing these publications that users recognise and abide by the legal requirements associated with these rights.

Take down policy

The Research Portal is Queen's institutional repository that provides access to Queen's research output. Every effort has been made to ensure that content in the Research Portal does not infringe any person's rights, or applicable UK laws. If you discover content in the Research Portal that you believe breaches copyright or violates any law, please contact openaccess@qub.ac.uk. 


\section{Public Choice}

\section{Public Resource Allocation, Strategic Behavior, and Status Quo Bias in Choice Experiments \\ --Manuscript Draft--}

\begin{tabular}{|c|c|}
\hline Manuscript Number: & PUCH-D-19-00225R2 \\
\hline Full Title: & $\begin{array}{l}\text { Public Resource Allocation, Strategic Behavior, and Status Quo Bias in Choice } \\
\text { Experiments * }\end{array}$ \\
\hline Article Type: & Original Research \\
\hline Keywords: & choice experiment; strategic voting; status quo bias; public goods experiment \\
\hline Corresponding Author: & $\begin{array}{l}\text { Katherine Silz-Carson, Ph.D. } \\
\text { U.S. Air Force Academy } \\
\text { USAF Academy, CO UNITED STATES }\end{array}$ \\
\hline \multicolumn{2}{|l|}{$\begin{array}{l}\text { Corresponding Author Secondary } \\
\text { Information: }\end{array}$} \\
\hline Corresponding Author's Institution: & U.S. Air Force Academy \\
\hline \multicolumn{2}{|l|}{$\begin{array}{l}\text { Corresponding Author's Secondary } \\
\text { Institution: }\end{array}$} \\
\hline First Author: & Katherine Silz-Carson, Ph.D. \\
\hline \multicolumn{2}{|l|}{ First Author Secondary Information: } \\
\hline \multirow[t]{4}{*}{ Order of Authors: } & Katherine Silz-Carson, Ph.D. \\
\hline & Susan M. Chilton \\
\hline & W. George Hutchinson \\
\hline & Riccardo Scarpa \\
\hline \multicolumn{2}{|c|}{ Order of Authors Secondary Information: } \\
\hline \multicolumn{2}{|l|}{ Funding Information: } \\
\hline Abstract: & $\begin{array}{l}\text { Choice experiments, a survey methodology in which consumers face a series of choice } \\
\text { tasks requiring them to indicate their most preferred option from a choice set containing } \\
\text { two or more options are used to generate estimates of consumer preferences to } \\
\text { determine the appropriate allocation of public resources to competing projects or } \\
\text { programs. The analysis of choice-experimental data typically relies on the } \\
\text { assumptions that choices of the non-status quo option are demand-revealing and } \\
\text { choices of the status quo option are not demand-revealing, but, rather, reflect an } \\
\text { underlying behavioral bias in favor of the status quo. This paper reports the results of } \\
\text { an experiment demonstrating that both of those assumptions are likely to be invalid. } \\
\text { We demonstrate that choice experiments for a public good are vulnerable to the same } \\
\text { types of strategic voting that affect other types of multiple-choice voting mechanisms. } \\
\text { We show that owing to the mathematics of choice-set design, what actually is strategic } \\
\text { voting often is misinterpreted as a behavioral bias for the status quo option. Therefore, } \\
\text { we caution against using current choice-experimental methodologies to inform policy } \\
\text { making about public goods. }\end{array}$ \\
\hline Response to Reviewers: & $\begin{array}{l}\text { All changes requested by the editor have been made. Reprint permissions for figures } \\
\text { have been obtained. All figures attached as TIFF files. }\end{array}$ \\
\hline
\end{tabular}




\title{
Public Resource Allocation, Strategic Behavior, and Status Quo Bias in Choice
}

\author{
Experiments *
}

\author{
Katherine Silz Carson ${ }^{\mathrm{a}}$ \\ aDepartment of Economics and Geosciences, United States Air Force Academy \\ 2354 Fairchild Drive, Suite 6K110, USAF Academy, CO 80840-6299 USA \\ Katherine.Silz-Carson@usafa.edu
}

\author{
Susan M. Chilton ${ }^{\mathrm{b}}$ \\ ${ }^{b}$ Newcastle University Business School - Economics \\ 5, Barrack Road, Newcastle upon Tyne, NE1 4SE, UK \\ susan.chilton@ncl.ac.uk
}

W. George Hutchinson ${ }^{c}$

${ }^{\mathrm{c}}$ Gibson Institute for Land, Food and Environment, Institute for Global Food Security, and CRC

Centre of Excellence for Public Health, Queen's University, Belfast

MBC, 97 Lisburn Road, Belfast, BT9 7BL, UK

g.hutchinson@qub.ac.uk

\author{
Riccardo Scarpa ${ }^{\mathrm{d}}$ \\ ${ }^{\mathrm{d} D u r h a m}$ University Business School, Durham, UK \\ Mill Hill Lane, Durham, DH1 3LB, UK \\ riccardo.scarpa@durham.ac.uk
}

Corresponding Author:

Katherine Silz Carson

719-333-2597

Katherine.Silz-Carson@usafa.edu

*This research is funded by Queen's University, Belfast, under a cooperative research and development agreement with the United States Air Force Academy. The funding was for payment of experimental subjects only. Sponsor had no role in study design; collection, analysis, and interpretation of data; writing of the report; or decision to submit the article for publication. The opinions expressed herein are solely those of the authors and do not necessarily reflect the views of the authors' respective institutions.

Declarations of interest:

Hutchinson: Employed as a consultant by Northern Ireland Electricity Networks Ltd in connection with the preparation of the $6^{\text {th }}$ Price Control Agreement (RP6) with The Office of the Utility Regulator NI (Final Determination $30^{\text {th }}$ June 2017). Study is cited herein as Queen's University Belfast and Perceptive Insight (2015).

Scarpa: Served as lead consultant in the design of the survey instruments and the choice data analysis for the study for the Australian Energy Market Operator cited herein.

Compliance with ethical standards: This research involves human participants. The experiments reported herein were conducted under the oversight of the United States Air Force Academy Institutional Review Board, protocol number FAC20130036H. All participants provided signed informed consent prior to participating in this research. 


\title{
Public resource allocation, strategic behavior and status quo bias in choice experiments
}

\begin{abstract}
Choice experiments, a survey methodology in which consumers face a series of choice tasks requiring them to indicate their most preferred option from a choice set containing two or more options are used to generate estimates of consumer preferences to determine the appropriate allocation of public resources to competing projects or programs. The analysis of choiceexperimental data typically relies on the assumptions that choices of the non-status quo option are demand-revealing and choices of the status quo option are not demand-revealing, but, rather, reflect an underlying behavioral bias in favor of the status quo. This paper reports the results of an experiment demonstrating that both of those assumptions are likely to be invalid. We demonstrate that choice experiments for a public good are vulnerable to the same types of strategic voting that affect other types of multiple-choice voting mechanisms. We show that owing to the mathematics of choice-set design, what actually is strategic voting often is misinterpreted as a behavioral bias for the status quo option. Therefore, we caution against using current choice-experimental methodologies to inform policy making about public goods.
\end{abstract}

Keywords: choice experiment, strategic voting, status quo bias, public goods experiment JEL codes: H41, C91, C92 


\section{Public resource allocation, strategic behavior and status quo bias in choice experiments}

\section{Introduction}

This paper cautions against the growing use and dominance of the choice experimental method to generate estimates of the benefits received from public policies and programs. "Choice experiments" (CEs), a survey method used to uncover consumer preferences, initially were developed and now are used widely in the context of private goods studied by scholars in marketing and transport to reveal consumer preferences and predict market shares for new products (e.g., Louviere and Woodworth 1983; Louviere 1984, 1988; Revelt and Train 1998; Brownstone and Train 1999; McFadden 2001; Hensher, Rose and Greene 2015). However, the methodology soon was applied to informing administrators of public programs and policies in the environmental and healthcare domains, whose outputs largely (or solely) are public goods (e.g., Australian Energy Market Operator 2014; Cameron and DeShazo 2013; Emmerson and Metcalfe 2013; Queen's University Belfast and Perceptive Insight 2015). Choice-experiment mechanisms can take a variety of forms such as one-shot or repeated choice tasks. On each choice task, participants are presented with a choice set containing two or more options from which they must choose one. In order to be consistent with market settings in which consumers always have the option not to purchase anything, in most choice experiments, one of the options in each choice task always is a 'no purchase' (in CEs for private goods) or 'status quo' (in CEs for public goods) alternative. Figure 1 reports example choice tasks from choice experiment surveys used in three very different settings: to estimate the demand for quality-differentiated beef (Lusk and Schroeder 2004); to determine the public's preferences for public lands' use for endangered species protection versus military training (Smith and McKee 2007); and to estimate preferences for a cervical cancer screening program (Ryan and Wordsworth 2000). The common 
features of the relevant experimental designs are (1) choice options described in terms of their characteristics, termed attributes, which vary across options; (2) the offer of more than two options from which respondents may choose; (3) information about a price or cost attribute for each option (which enables researchers to estimate willingness to pay); and (4) the presence of a no purchase/no policy change (status quo) option. Because of the gains in statistical efficiency of preference estimates that result from asking respondents to choose from more than two options and presenting respondents with more than one choice task (both of which generate more information about each respondent's preferences, resulting in greater statistical efficiency), most choice experiment surveys employ a repeated multiple choice mechanism, in which participants complete a series of choice tasks similar to those presented in Figure 1. As respondents proceed through the tasks, the characteristics of the purchase/non-status-quo options change, while the characteristics of the no purchase/status quo option remain the same. Using logit-based econometric techniques (McFadden 1986, 2001), researchers can use respondents' stated choices to estimate respondents' willingness to pay for a good or policy as well as their marginal willingness to pay for the attributes of a good or policy.

Although we might expect to obtain reliable preference estimates in the private goods domain, the application of the choice experiment domain to the public goods environment potentially is problematic. In particular, the possibility of strategically biased preference estimates in the public goods environment has been neglected in the literature to date. One of the most common biases in choice experiments that researchers have found is apparent overselection of the no purchase/status quo option (e.g., Collins and Vossler 2009; Adamowicz et al. 2011), termed status quo bias. The apparent bias in favor of the status quo option can 
significantly reduce the estimated value of the public good (Adamowicz et al. 1998), possibly resulting in misallocations of public resources. Although multiple explanations for the source of the bias have been advanced in the literature, ${ }^{1}$ as well as econometric methods (Adamowicz et al. 1998) to adjust benefit estimates for the presence of status quo bias, none of the existing studies considers the role that the underlying incentives of the choice mechanism in a public goods environment may play in generating bias. That neglect may be explained by the difficulties inherent in identifying strategic behavior in field survey data.

This paper takes the choice experiment out of the field and into the laboratory in order to establish whether choice experiments can generate unbiased estimates of the benefits received from public goods. By taking such an approach, we are able to demonstrate unambiguously that choice experiments for public goods are vulnerable to the same type of strategic voting that occurs in multi-candidate elections. Strategic choices center on the second-best option, which, because of the mathematics of combinatorial choice set design, ${ }^{2}$ is the status quo option in a disproportionate number of choice tasks. The experimental results demonstrate that it is inappropriate to interpret the results from choice experiments as either fully demand-revealing, or as demand-revealing with an adjustment for status quo bias. Both interpretations of choice experimental data can result in biased estimates of preferences for public goods and, thus, misallocations of public resources. Because of that potential problem, we argue that current choice experiment methods to value public goods should be used with caution.

\footnotetext{
${ }^{1}$ See, for example, List et al. (2006), Taylor et al. (2010), Carlsson et al. (2007), Bateman et al. (2008), Collins and Vossler (2009), Day and Pinto-Prades (2010), Day et al. (2012) and Aravena et al. (2014).

${ }^{2}$ By the "mathematics of combinatorial choice set design", we mean the method by which individual choice options with different levels of attributes are combined into groups of options, termed choice sets. During a choice experimental survey, respondents are presented with a series of tasks, in which they are asked to choose one option from each choice set. Their selection usually is interpreted to indicate the most preferred option in the set.
} 
We provide three forms of support for this argument: (1) well-known results from the theoretical and applied literature on strategic voting demonstrating voters' incentives to choose their second favorite option in races involving three or more candidates; (2) a model demonstrating how the mathematics of combinatorial choice set design can result in choice experiments in which a large fraction of choice tasks contain the status quo option as the secondbest choice; and (3) evidence from an experiment based on three fractional factorial designs showing that behavior in such choice experiments is consistent with the predictions of voting theory. The remainder of this paper lays out the argument by presenting the theoretical and mathematical models in section 2, the experimental design in section 3 , the results in section 4 , and concluding remarks in section 5 .

\section{Theory and simulations}

\subsection{Voting in multi-candidate elections}

As the theory of voting is well-known, we provide only a brief summary of it here. Farquharson (1969) provides a comprehensive overview of the topic. Consider a group of $n$ agents voting on the choice of a public program or policy. Suppose that agents choose from three discrete public goods, $g \in\{A, B, C\}$. Each agent $i$ has a complete, reflexive and transitive preference ordering over the three proposed programs, which can be represented by a utility function $u_{i}(g)$. In order to determine which program to provide, the public agency conducts a vote. Each agent $i$ casts a vote $v_{i}(g)$. Under a plurality voting rule, the agency's decision is to provide the public program that receives the most votes, $g^{*}$. Thus, each agent's problem is to choose his or her vote $v_{i}(g)$ to maximize own-utility, $u_{i}(g)$, conditional on the distribution of votes of the other group members. In the case of uniform priors, in which agent $i$ believes that the other group members' votes are distributed equally across the three outcomes, agent $i$ 's best response is to vote for his or her 
most preferred option. In that case, agent $i$ 's vote is demand-revealing. However, if agent $i$ has non-uniform priors about the distribution of others' votes, the voter may have incentive to vote for an option other than the one he or she most prefers. For example, if agent $i$ 's preferences are such that $u_{i}(A)>u_{i}(B)>u_{i}(C)$, but her priors are

$$
\sum_{j \neq i} v_{j}(C)>\sum_{j \neq i} v_{j}(B)>\sum_{j \neq i} v_{j}(A)
$$

then agent $i$ can potentially improve her utility by voting for her second most-preferred option rather than her most preferred option, in order to prevent the least-preferred option from winning. In such cases, agent $i$ 's vote is not demand-revealing.

Strategic voting of that type is perhaps the most well-known result of voting theory. It has been demonstrated to occur in laboratory settings under conditions of full information about the distribution of the preferences of the other voters (Felsenthal et al. 1988; Forsythe et al. 1993; Meginnis et al. 2018) and in field settings wherein voters have only partial information about the distribution of other voters' preferences (Fujiwara 2011; Kawai and Watanabe 2013). Given that the incentive structure of each choice task in a choice experiment mechanism for a public good is identical to that of a multi-candidate election, it is reasonable to expect that a similar type of strategic voting might take place in choice experiment surveys. We demonstrate below that owing to the mathematics of combinatorial choice set design, strategic votes for the second-best option are likely to disproportionately favor the status quo option.

\subsection{Combinatorial choice set design and the second-best option}

We begin with a few definitions:

Definition 1: A choice experiment is a survey in which a respondent faces a series of choice tasks such as the ones illustrated in Figure 1. On each choice task, the respondent faces a choice set from which s/he must select one option. 
Definition 2: A choice set is a collection of two or more choice options. The number of options in the choice sets illustrated in Figure 1 ranges from three (for the land use and health studies) to six (for the beef study). In most choice experiment surveys, including the ones illustrated in Figure 1, one of the choice options typically is the no purchase/status quo option. Definition 3: A choice option is a version of the good that the respondent may choose. Each choice option is described in terms of the quantity of each attribute it possesses. Choice options in Figure 1 include five different types of steak and a no purchase option, two alternative land use policies along with a keep current policy (status quo) option, and two alternative cancer screening program options along with a no screening option.

Definition 4: An attribute is a characteristic of a good. The amount of an attribute that a good possesses may be described using discrete or continuous numerical values. The cost or price of an option usually is one of the attributes in order to facilitate the estimation of a respondent's willingness to pay. In Figure 1, the attributes of the steaks are limited to their prices and a descriptor of their qualities (e.g., "Guaranteed Tender"). The attributes of the land use policy include the cost of each policy per household and the impact of the policy on species survival and soldiers' readiness (both of which can take on levels of low, medium, or high). Attributes of the cancer screening program include the time between Pap smears, the time to obtain results, the chance of being recalled, the chance of an abnormality being discovered, the chance of dying from cervical cancer, and the cost.

In the derivation that follows, we consider fundamental principles of attribute-balanced choice set design applied to experiments eliciting preferences for public goods. An attribute balanced choice set is a choice set in which every choice option is described using the same number of attributes, and each attribute has the same number of possible levels. In Figure 1, the 
choice sets in the land use study are attribute-balanced. The mathematical results below generalize easily to choice sets in which different attributes have different numbers of possible levels. ${ }^{3}$ In choice sets in which each of $m$ attributes has $n$ levels, $n^{m}$ possible choice options can be combined into choice sets. One of more of those options are combined with the status quo/no purchase option (whose attributes are fixed) to create a choice set. To illustrate the effect of such a choice set design process, we let $\pi$ represent the proportion of the non-status-quo choice options that are preferred by the voting public to the status quo. We make the simplifying assumption that all voters have the same value of $\pi$. The result generalizes to the more realistic assumption that the values of $\pi$ are distributed non-uniformly across the voting population. Therefore, given the values of $n, m$, and $\pi, \pi n^{m}$ choice options are preferred to the status quo option, and $(1-\pi) n^{m}$ choice options are not preferred to the status quo.

A choice experiment in which respondents face a sufficient number of options that they choose from all possible combinations in choice sets of a given size is termed a full factorial choice experiment. We consider a full factorial choice experiment in which on each choice task, respondents must choose from a three-option choice set consisting of two options plus the status quo. We focus our analysis on that type of choice experiment both because it is the simplest choice experimental design in which the choice tasks contain more than two options, and because such choice experimental designs are adopted frequently in applied public goods settings (Ferrini and Scarpa 2007). In a full factorial choice experiment in which each choice set contains two options plus the status quo, the total number of possible choice sets is $n^{m}\left(n^{m}-1\right)$. In $\left(\pi n^{m}\right)\left(\pi n^{m}-1\right)$ of those choice sets, the status quo will be the least-preferred option. In [(1$\left.\pi) n^{m}\right]\left[(1-\pi) n^{m}-1\right]$ of these choice sets, the status quo will be the most-preferred option.

\footnotetext{
${ }^{3} \mathrm{~A}$ proof of the generalized result is available from the authors.
} 
Those considerations yield

$$
n^{m}\left(n^{m}-1\right)-\left\{\pi n^{m}\left(\pi n^{m}-1\right)+\left[(1-\pi) n^{m}\right]\left[(1-\pi) n^{m}-1\right]\right\}
$$

choice sets in the full factorial design in which the status quo option is the second-best option. In the limit (as either $n \rightarrow \infty$ or $m \rightarrow \infty$ ), the ratio of this number to the total number of choice sets is $2 \pi(1-\pi)$. Furthermore, the limiting fraction of total possible choice sets in the full factorial design in which the status quo is either the most-preferred or second-most-preferred option is (1 $\left.-\pi^{2}\right)$.

[Insert Table 1 about here.]

\subsection{Calculations and simulation results}

The derivation above demonstrates that the status quo is likely to be the first-best or second-best position in a large fraction of choice sets. In a full factorial choice experiment in which half the options are preferred to the status quo and half are not $(\pi=0.50)$, the status quo will be the firstbest or second-best position in $\left(1-(0.5)^{2}\right)=75 \%$ of the choice sets. That result is for large values of $n$ or $m$ and all possible choice sets. Table 1 reports the proportion of choice sets in which the status quo option is first-best or second-best for small values of $n$ or $m$ when $\pi=0.5$. Table 1 shows that the limiting case is reached very quickly.

Typically, field choice experiments do not adopt full factorial designs, as they would require respondents to complete an inordinate number of choice tasks. Choice experiments using a subset of the choice sets from the full factorial design are termed fractional factorial choice experiments. We apply three techniques to derive fractional factorial choice experiment designs from the full factorial design to examine the extent to which the predictions of the mathematical model for the latter hold for the former. We derive designs for choice experiments containing 12 choice tasks in which the choice sets are either utility balanced (Huber and 
[Insert Table 2 about here.]

[Insert Table 3 about here.]

Zwerina 1996), orthogonal on the attribute level differences (Kanninen 2002; Street et al. 2005), or randomly drawn from the full factorial design. Each option in each choice set has three attributes, one of which is the cost, and each attribute has two possible levels. The status quo option contains baseline levels of each attribute at no cost. Table 2 illustrates a sample choice set used in the simulation. In order to generate a simulated voter's rank-ordering of the options in a choice set, we assume the following utility function:

Utility $=($ Marginal value of attribute $A \times$ Units of $A)+($ Marginal value of attribute $B \times$

$$
\text { Units of attribute B) - Cost. }
$$

By varying a voter's marginal valuations of the attributes in equation (3), we can vary the value of $\pi$ and calculate a voter's simulated utility for each choice option, as well as their rank-ordering of each choice option in each choice set. Table 3 reports the results of the simulations, and demonstrates that the mathematical predictions based on the value of $\pi$ applied to a full factorial design are reasonable estimates of the fraction of choice sets in a fractional factorial design that will contain the status quo as the second-best or first-best or second-best option.

Although the status quo option is likely to be the second-best position in a large percentage of choice sets, voters have incentive to cast non-demand revealing votes for the second-best option only if they hold non-uniform priors on the distribution of other voters' preferences. In order to examine whether the second condition is satisfied, we employ the orthogonal on the attribute level differences choice experiment design from the simulations in Table 3, and ask what the distribution of preferences over choice options in each choice set would be if the distribution of $\pi$ were uniform. Table 4 reports the results of that exercise. 
Uniform distributions of voter preferences over choice options clearly are not the norm, which means that it may not be reasonable to assume that voters have uniform priors about the distribution of votes. Thus, the conditions necessary for strategic voting appear to be present in choice experiments and, as a result of the mathematics of combinatorial choice set design, many of the strategic votes are likely to be for the status quo option, which will frequently fall in the second best position in a choice set.

\section{Experimental design}

\subsection{Rules of the game}

The experiment reported below is designed to simulate a field choice experiment. In the experiment, subjects in groups of nine, which remain the same for the entire experimental session, vote on a series of 12 ballots for a public good, which for the purposes of the experiment is characterized as a group investment for which earnings vary across subjects. Each ballot contains a choice set containing three options. Each option has two attributes and a cost. We reserve additional details about the choice sets for the following section on induced values.

The order of ballots is randomized across subjects. Subjects complete each ballot one by one and submit them to the experimental moderator. All ballots are cast privately; each subject sees the information only on his or her own ballot. After the 12 rounds of voting are completed, one ballot is selected randomly from the 12 to be binding using the roll of a 12-sided die. The votes on the binding ballot are counted and a plurality voting rule is applied, so that the choice option on the binding ballot with the most votes wins. Two-way ties are resolved using the toss of a fair coin, and three-way ties are resolved by rolling a fair six-sided die. The winning option is announced, and subjects compute their earnings for the winning option using the formula: 
[Insert Figure 2 about here.]

Earnings $=6+($ Marginal value of attribute $A \times$ Units of attribute $A)+($ Marginal value of attribute B $\times$ Units of attribute B) - Cost

Subjects know all of the rules of the game at the beginning of the experiment. Each subject knows that other members of the group may face a different set of choice options on any given ballot and that other subjects also may have different marginal values for each attribute, but no subject knows the overall distribution of marginal values or possible choice options. Figure 2 presents a sample ballot.

\subsection{Choice set designs}

Each choice option contains three attributes (A, B and Cost) with two levels. Attribute A has possible levels of 1 or 2, Attribute B has possible levels of 1 or 3 , and the Cost is either 5 or 10 . This design is the simplest possible design that mimics a field choice experiment. A full factorial choice experiment design contains $2^{3}=8$ possible choice options which can be combined into 56 possible multiple-choice sets containing two different options and the status quo option. The status quo option contains 1 unit of attribute $A, 1$ unit of attribute $B$, and is available at zero cost.

In order to test whether behavior differs in different types of choice experiment designs, we employ three methods to reduce the number of choice sets from the full factorial: orthogonality on the attribute level differences (Kanninen 2002; Street et al. 2005), utility balance (Huber and Zwerina 1996) and random. In an orthogonal choice set in which each attribute has only two levels, if one attribute of one option in the set has the high level, that same attribute in the other option in the choice set will be assigned the low level. Thus, the smallest possible choice experiment that results from a $2^{3}$ factorial design is one containing 12 choice 
sets. For consistency, choice experiments designed using the random and utility balanced methodologies also contain 12 choice sets. Normally, to create utility-balanced choice sets, the designer would have to make assumptions regarding the choice options that are likely to be considered better or worse by respondents in order to generate the property of utility balance. In an induced-value setting, subjects' induced utility for each choice option is known in accordance with earnings equation (4). Thus, we create a different set of utility-balanced choice sets for each set of induced values. All choice set designs are reported in the supplemental materials.

[Insert Table 5 about here.]

\subsection{Induced values}

The experimental design incorporates three sets of induced values, corresponding to $\pi$ values of $0.125,0.50$ and 0.75 . Table 5 reports the marginal values of attributes A and B associated with each value of $\pi$.

The combination of three methods to create fractional factorial choice experimental designs and three sets of induced values results in nine experimental conditions. Within an experimental session, which could contain up to 27 participants, subjects are assigned randomly to a group of nine that play either the orthogonal, utility-balanced or random version of the choice experiment. ${ }^{4}$ Within a group of nine, each subject is assigned randomly an induced value. Subjects are blinded to the method by which their choice sets were created, the induced values of the other individuals in their group, and the overall distribution of induced values. Moderators also are blinded to the distribution of induced values in the group. Two-hundred-and-seventy student volunteers from a US university participated in the experiment, resulting in a sample of

\footnotetext{
${ }^{4}$ If the number of subjects who showed up was not divisible by nine, the unassigned subjects were invited to participate in a different experimental session at a later time. Prior to starting the experiment, all subjects completed an informed consent process. Subjects were free to leave at any time.
} 
30 subjects for each choice experiment design-induced value combination. Since each subject votes 12 times, a total of 360 observations per choice experiment design-induced value combination were collected, or 1080 total observations for each choice experiment design methodology. The experiment takes 40 to 45 minutes to complete, and average experimental earnings ranged from $\$ 15$ to $\$ 20 .{ }^{5}$

\section{Results and discussion}

The results to be reported demonstrate that (1) strategic voting occurs in choice experiments for public goods; (2) strategic votes for the status quo option happen a predictable percentage of the time; and (3) most choices of the status quo option are not examples of status quo bias, but rather, are demand-revealing. As a consequence, it is inappropriate to interpret the data from choice experiments as either fully demand-revealing, or as subject to a behavioral bias in favor of the status quo. Public policy choices informed by analyses based on either of those two interpretations may result in inefficient allocations of public resources. In the discussion that follows, all p-values are calculated using standard errors clustered at the individual subject level to account for within-subject correlation of errors. ${ }^{6}$

4.1 Result 1: Strategic voting occurs in choice experiments for public goods.

One-hundred-fourteen subjects ( $42 \%$ of all subjects) cast at least one vote for the second-best option in a choice set during the experiment. As reported in Table 6, votes for the second-best option constitute over $70 \%$ of all non-demand revealing votes. Conditional on a vote being non-

\footnotetext{
${ }^{5}$ The experiment was conducted under the oversight of the university's Institutional Review Board (IRB). All experimental instructions are available in the online supplementary materials. Experimental data are available from the corresponding author upon request.

${ }^{6}$ As a check, we re-calculated all standard errors and p-values by controlling for clustering at the group level instead of at the subject level. Generally speaking, standard errors and p-values when controlling for clustering at the group level are the same or smaller than when controlling for non-independence at the individual subject level. Controlling for non-independence at the group level does not change any of the conclusions reported below.
} 
[Insert Table 6 about here.]

demand revealing, no significant differences are found in the fractions of votes for the secondbest alternative across choice experiment design treatments $(0.55 \leq p \leq 0.90)$. Subjects with low values of $\pi$ are significantly more likely than other subjects to vote for the second-best option ( $p$ $<0.01)$. No other significant differences are evident in the nature of non-demand revealing behavior across subject types.

[Insert Figure 3 about here.]

[Insert Figure 4 about here.]

Figure 3 reports the frequency of the total number of second-best votes cast by individual subjects. The vast majority of subjects who cast second-best votes cast one or two votes for the second-best option out of a possible 12. Subjects tend to vote for the second-best option when a very bad third option is offered in a choice set. Including the status quo option, nine possible choice options can be combined into choice sets. Figure 4 reports the ranking out of nine of the worst option in each choice set for those ballots for which non-demand revealing votes were cast for the second-best alternative. When subjects cast a non-demand revealing vote for the secondbest alternative, $65 \%$ of the time the ballot contained a third option that ranked $7^{\text {th }}, 8^{\text {th }}$, or $9^{\text {th }}$ out of the possible nine alternatives. Seventy-nine percent of those ballots contained a third alternative that fell in the bottom half of the ranking. Most non-demand revealing votes are for the second-best option, tend to occur when a bad third option is included in the choice set and tend to be cast more often by the $\pi=0.125$ subjects (who have many more bad options in their choice sets). The combination of these three results demonstrates that non-demand revealing behavior is not random, but rather follows a pattern consistent with a model of strategic voting. 
The overall rate of strategic voting in the experiment is $8 \%$. That frequency of strategic voting is well within the range of rates of strategic voting observed previously in the laboratory (as high as 50\%, as reported in Felsenthal et al. 1988; Forsythe et al. 1993) and in the field (1.2\%, as reported in Kawai and Watanabe 2013). In most laboratory studies of strategic voting, subjects have complete information about the distribution of other voters' preferences, providing full information about non-uniform priors and making the incentives for strategic voting completely transparent. Obviously, such information is not available to voters in the field. In the experiment at hand, subjects have complete information about their own preferences (as in other laboratory studies), but must form their own priors about the distribution of preferences of other members of the group (as in field studies). Given that the experimental design contains elements of both the lab and the field, it is not surprising to observe rates of strategic voting that are consistent with and within the range of results reported previously from the lab and the field.

[Insert Table 7 about here.]

\subsection{Result 2: Strategic votes for the status quo option happen a predictable percentage of the time.}

The first five rows of Table 7 report the predicted fractions of votes for the second-best option when that option is the status quo. The last three rows of Table 7 show the observed fraction of second-best votes for the status quo. By comparing the last three rows to the rows above them, it is possible to examine the extent to which strategic votes for the status quo are consistent with the mathematical predictions based on the value of $\pi$.

Subjects may deviate from those predictions by casting a second-best vote for the status quo more or less often than predicted by the model, depending on when they choose to cast votes for a second-best option. If they are casting second-best votes more often in choice tasks in 
which the status quo is not in the second-best position, the observed fraction of second-best votes for the status quo option will be less than predicted by the value of $\pi$. If they are casting secondbest votes more often on choice tasks when the status quo is in the second-best position, then the observed fraction of second-best votes for the status quo will be greater than predicted by the value of $\pi$. Both outcomes are observable in Table 7. The choice tasks on which subjects may choose to cast second-best votes depends on a subject's priors and how bad the third alternative is for them, which varies across choice sets and by values of $\pi$. The exceptions to that conclusion are the orthogonal choice sets for $\pi=0.50$ subjects. Since all of the orthogonal choice sets contain the status quo in the second-best position, all second-best votes necessarily are cast for the status quo alternative. The key message of Table 7 is, with the exception of the utlity-balanced treatment, that the fraction of second-best votes for the status quo generally is consistent with the mathematical predictions based on the value of $\pi$. Thus, strategic votes for the status quo as the second-best option happen a predictable percentage of the time.

\section{[Insert Table 8 about here.]}

\subsection{Result 3: Most choices of the status quo option are not examples of status quo bias, but rather, are demand-revealing choices.}

Table 8 reports the overall rates of demand revelation by choice experiment design methodology and $\pi$. Although some differences in rates of demand revelation by choice experiment design are evident, ${ }^{7}$ the main message of the table is about how demand revelation differs by value of $\pi$. Overall, subjects who have low values of $\pi$ are significantly less likely to cast a demandrevealing vote than other subjects $(p=0.03$ for $\pi=0.125$ versus $0.50 ; p=0.02$ for $\pi=0.125$

\footnotetext{
${ }^{7}$ The overall rate of demand revelation is significantly less in the UBAL treatment than the OOD treatment $(\mathrm{p}=$ 0.02). No other significant differences in rates of demand revelation are evident across methods to create fractional factorial choice experiment designs.
} 
versus 0.75 ). Such subjects prefer the status quo to most of the other available choice options and have many bad options in the choice sets that they face. They are precisely the subjects whom voting theory predicts are likely to vote strategically, which is what we observe in Table

8.

\section{[Insert Table 9 about here.]}

Although the results demonstrate that strategic votes for the second-best option are cast for the status quo option in a predictable fraction of choices, it likewise is the case that most votes for the status quo option are not strategic, but rather are demand-revealing. Table 9 reports the fraction of status quo votes that are demand revealing. That fraction differs significantly $(p<$ 0.01 for all differences) by a subject's value of $\pi$ in exactly the direction predicted by the mathematics of combinatorial choice set design. Those subjects who have very few choice options that are better than the status quo (those with $\pi=0.125$ ) cast demand-revealing votes frequently for the status quo, while those who have many choice options that are better than the status quo $(\pi=0.75)$ cast demand-revealing votes for the status quo much less often. Of 1031 total votes for the status quo, 954 are demand-revealing. Of the 77 votes that remain, 54 (70\%) are strategic votes for the status quo when it is the second-best option in the choice set. Thus, only 23 votes for the status quo, of a total of 1031 status quo votes cast, appear to exhibit what we might term "status quo bias". Thus, when the incentives of the choice mechanism are accounted for, status quo bias appears to be a rare phenomenon in choice experiments for a public good.

\section{Conclusion}

Moving from the laboratory to the field, the results reported herein have clear implications for any application of choice experimental data to public decision-making. When choice experiment 
data are analyzed to generate estimates of consumer preferences for use in determining the appropriate allocation of public resources to competing projects or programs, normally the data analysis hinges on two assumptions: (1) choices of the non-status quo option are demandrevealing; and (2) choices of the status quo-option are not true reflections of underlying preferences, but rather reflect an underlying behavioral bias in favor of the status quo. The experimental results reported here, which are robust to the types of choice experiment design methodologies tested, demonstrate that both assumptions are likely to be invalid. The only reason that non-demand revealing choices center more often on the status quo option is because the status quo option appears in every choice set, and owing to the mathematics of combinatorial choice set design, is likely to rank in first-best or second-best position in a choice set a large percentage of the time. Because it is easier to distinguish choices of the status quo from other choices in the data, the apparent over-selection of the status quo has been interpreted to reflect behavioral bias on the part of consumers. The experiment in this paper demonstrates that it is far more likely that consumers are making either a demand-revealing choice of their favorite option in the choice set, or a strategic choice of the second-best option in order to prevent a very bad third option from winning. Failure to account for the incentive structures inherent in the multiple-choice voting mechanism for public goods is likely to result in mis-estimation of preferences and, hence, misallocation of public resources. Thus, we caution against the use of the choice experiment methodology as currently practiced as a way of informing public policy decisions.

Based on the results, we recommend that, in the future, researchers focus their attention on developing new mechanism designs that are free of the incentive properties that we describe 
herein or use alternative methods to analyze choice data that exploit the information that is present in a respondent's choice of the second-best option. 


\section{References}

Adamowicz, W., Boxall, P., Williams, M., \& Louviere, J. (1998). Stated preference approaches for measuring passive use values: choice experiments and contingent valuation. American Journal of Agricultural Economics, 80(1), 64-75.

Adamowicz. W., Dupont, D., Krupnick, A., \& Zhang, J. (2011). Valuation of cancer and microbial disease risk reductions in municipal drinking water: an analysis of risk context using multiple valuation methods. Journal of Environmental Economics and Management, 61(2), 213226.

Aravena, C., Martinsson, P., \& Scarpa, R. (2014). Does money talk? - the effect of a monetary attribute on the marginal values in a choice experiment. Energy Economics, 44, 483-491. Australian Energy Market Operator (2014), Value of customer reliability review: final report. http://www.aemo.com.au/-/media/Files/PDF/VCR-final-report--PDF-update-27-Nov-14.pdf Bateman, I., Munro, A., \& Poe, G. (2008). Decoy effects in choice experiments and contingent valuation: asymmetric dominance. Land Economics, 84(1), 115-127.

Brownstone, D. \& Train, K. (1999). Forecasting new product penetration with flexible substitution patterns. Journal of Econometrics, 89, 109-129.

Cameron, T. \& DeShazo. J. (2013). Demand for health risk reductions. Journal of Environmental Economics and Management, 65(1), 87-109.

Carlsson, F., Frykblom, P., \& Lagerkvist, C. (2007). Preferences with and without prices - does the price attribute affect behavior in stated preference surveys? Environmental and Resource Economics, 38,155-164.

Collins, J. \& Vossler, C. (2009). Incentive compatibility tests of choice experiment value elicitation questions. Journal of Environmental Economics and Management, 58(2), 226-235. 
Day, B., Bateman, I., Carson, R., Dupont, D., Louviere, J., Morimoto, S., Scarpa, R., \& Wang, P. (2012). Ordering effects and choice set awareness in repeat-response stated preference studies. Journal of Environmental Economics and Management, 63, 73-91.

Day, B. \& Pinto Prades, J. (2010). Ordering anomalies in choice experiments. Journal of Environmental Economics and Management, 59(3), 271-285.

Emmerson, C., \& Metcalfe, P. (2013). Southern water customer engagement (economic) willingness to pay, Report prepared for Southern Water UK, https://www.southernwater.co.uk/Media/Default/PDFs/A05_WillingnessToPay.pdf (accessed 14 Feb 2019).

Farquharson, R. (1969). Theory of voting. New Haven: Yale University Press.

Felsenthal D., Rapoport, A. \& Maoz, Z. (1988). Tacit cooperation in three alternative noncooperative voting games: A new model of sophisticated behavior under plurality procedure. Election Studies, 7, 143-161.

Ferrini, S. \& Scarpa, R. (2007). Designs with a priori information for nonmarket valuation with choice experiments: a Monte Carlo study. Journal of Environmental Economics and Management, 53, 342-363.

Forsythe, R., Myerson, R., Rietz, T., \& Weber, R. (1993). An experiment on coordination in multi-candidate elections: the importance of polls and election histories, Social Choice and Welfare, 10(3), 223-247.

Fujiwara, T. (2011). A regression discontinuity test of strategic voting and Duverger's law. Quarterly Journal of Political Science, 6, 197-233.

Hensher, D., Rose, J., \& Greene, W. (2015). Applied Choice Analysis, Second Edition. ed. Cambridge, UK: Cambridge University Press. 
Huber, J. \& Zwerina, K. (1996). The importance of utility balance in efficient choice designs. Journal of Marketing Research, 33(3), 307-317.

Kanninen, B. (2002). Optimal design for multinomial choice experiments. Journal of Marketing Research, 39(2), 214-227.

Kawai, K. \& Watanabe, Y. (2013). Inferring strategic voting. American Economic Review, 103(2), 624-662. http://dx.doi.org/10.1257/aer.103.2.624

List, J., Sinha, P., \& Taylor, M. (2006). Using choice experiments to value non-market goods and services: evidence from field experiments. Advances in Economic Analysis and Policy, 5(2), 1132. https://doi.org/10.2202/1538-0637.1132

Louviere, J. (1984). Using discrete choice experiments and multinomial logit choice models to forecast trial in a competitive retail environment: a fast food restaurant illustration. Journal of Retailing, 60(4), 81-108.

Louviere, J. (1988). Conjoint analysis modeling of stated preferences: a review of theory, methods, recent developments and external validity. Journal of Transport Economics and Policy, $10,93-119$.

Louviere, J. \& Woodworth, G. (1983). Design and analysis of simulated consumer choice or allocation experiments: an approach based on aggregate data. Journal of Marketing Research, 20, 350-367.

Lusk, J. \& Schroeder, T. (2004). Are choice experiments incentive compatible? A test with quality-differentiated beef steaks. American Journal of Agricultural Economics, 86(2), 467-482. McFadden, D. (1986). The choice theory approach to market research. Marketing Science, 5(4), 275-297.

McFadden, D. (2001). Economic choices. American Economic Review, 91(3), 351-378. 
Meginnis, K., Burton, M., Chan, R., \& Rigby, D. (2018). Strategic bias in discrete choice experiments. Journal of Environmental Economics and Management, https://doi.org/10.1016/j.jeem.2018.08.010.

Queens University Belfast and Perceptive Insight (2015). Discrete choice experiments for valuing the benefits of improved NIE services. Report prepared for Northern Ireland Electricity Networks. https://www.nienetworks.co.uk/documents/consultations/nie-wtp-report-5nov2015. Revelt, D. \& Train, K. (1998). Mixed logit with repeated choices: households' choices of appliance efficiency level. Review of Economics and Statistics, 80(4), 647-657.

Ryan, M. \& Wordsworth, S. (2000). Sensitivity of willingness to pay estimates to the level of attributes in discrete choice experiments. Scottish Journal of Political Economy, 47(5), 504-524. Street, D., Burgess, L., \& Louviere, J. (2005). Quick and easy choice sets: constructing optimal and nearly optimal stated choice experiments. International Journal of Research in Marketing, 22, 459-470. doi:10.1016/j.jiresmar.2005.09.003

Smith, J. \& McKee, M. (2007). 'People or prairie chickens' revisited: stated preferences with explicit non-market trade-offs. Defence and Peace Economics, 18(3), 223-244.

Taylor, L., Morrison, M., \& Boyle, K. (2010). Exchange rules and incentive compatibility of choice experiments. Environmental and Resource Economics, 47(2), 197-220. 


\begin{tabular}{|c|c|c|c|c|c|}
\hline \multicolumn{6}{|c|}{ Number of attributes $(m)$} \\
\hline \multirow{4}{*}{ 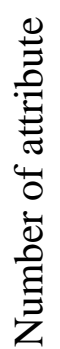 } & \multirow{4}{*}{$\begin{array}{l}\text { E } \\
\frac{0}{0} \\
0 \\
0\end{array}$} & & 2 & 3 & 4 \\
\hline & & 2 & 0.833 & 0.786 & 0.767 \\
\hline & & 3 & 0.781 & 0.760 & 0.753 \\
\hline & & 4 & 0.767 & 0.754 & 0.751 \\
\hline
\end{tabular}

Table 1. Proportion of choice sets with status quo as first-best or second-best option when

$$
\pi=0.5
$$




\begin{tabular}{|ccc|}
\hline$\underline{\text { Option 1 }}$ & Option 2 & Option 3 (current portfolio) \\
1 unit of A & 2 units of A & 1 unit of A \\
3 units of B & 1 unit of B & 1 unit of B \\
Cost $=5$ & Cost = 10 & Cost $=0$ \\
\hline
\end{tabular}

Table 2. Sample choice set from a simulation exercise 
Table 3. Full-factorial predictions of fractions of choice sets containing status quo as second-best or first- or second-best option versus actual results for fractional factorial choice experiment designs 


\begin{tabular}{|c|c|c|c|}
\hline Choice set & $\begin{array}{c}\text { Share preferring } \\
\text { Option 1 }\end{array}$ & $\begin{array}{c}\text { Share preferring } \\
\text { Option 2 }\end{array}$ & $\begin{array}{c}\text { Share preferring the } \\
\text { status quo }\end{array}$ \\
\hline 1 & $0 \%$ & $57 \%$ & $43 \%$ \\
\hline 2 & $86 \%$ & $0 \%$ & $14 \%$ \\
\hline 3 & $86 \%$ & $0 \%$ & $14 \%$ \\
\hline 4 & $0 \%$ & $57 \%$ & $43 \%$ \\
\hline 5 & $71 \%$ & $0 \%$ & $29 \%$ \\
\hline 6 & $14 \%$ & $29 \%$ & $57 \%$ \\
\hline 7 & $0 \%$ & $86 \%$ & $14 \%$ \\
\hline 8 & $29 \%$ & $14 \%$ & $57 \%$ \\
\hline 9 & $0 \%$ & $71 \%$ & $29 \%$ \\
\hline 10 & $0 \%$ & $14 \%$ & $57 \%$ \\
\hline 11 & $57 \%$ & $71 \%$ & $29 \%$ \\
\hline 12 & & $0 \%$ & $43 \%$ \\
\hline
\end{tabular}

Table 4. Distribution of voter preferences assuming a uniform distribution of $\pi$ 


\begin{tabular}{|c|c|c|}
\hline$\pi$ & Marginal value of attribute A & Marginal value of attribute B \\
\hline 0.125 & 3 & 2 \\
\hline 0.50 & 3 & 7 \\
\hline 0.75 & 11 & 7 \\
\hline
\end{tabular}

Table 5. Induced values 


\begin{tabular}{|r|c|c|c|}
\hline & Mean & Robust std. error & $95 \%$ conf. int. \\
\hline \multicolumn{3}{|c|}{ By method to create fractional factorial choice set designs } \\
\hline Orthogonal & 0.79 & 0.051 & {$[0.69,0.89]$} \\
\hline Utility-balanced & 0.82 & 0.050 & {$[0.72,0.92]$} \\
\hline Random & 0.83 & 0.046 & {$[0.74,0.92]$} \\
\hline By fraction of choice options preferred to the status quo $(\pi)$ \\
\hline$\pi=0.125$ & 0.87 & 0.035 & {$[0.80,0.94]$} \\
\hline$\pi=0.50$ & 0.79 & 0.048 & {$[0.70,0.89]$} \\
\hline$\pi=0.75$ & 0.73 & 0.064 & {$[0.61,0.86]$} \\
\hline
\end{tabular}

Table 6. Fraction of non-demand revealing votes for the second-best alternative 
Fraction of choice sets in which the status quo is second-best

\begin{tabular}{|l|c|c|c|}
\hline & $\pi=0.125$ & $\pi=0.50$ & $\pi=0.75$ \\
\hline Full factorial prediction: $n=2, m=3$ & 0.25 & 0.57 & 0.43 \\
\hline Full factorial prediction: limiting case & 0.22 & 0.50 & 0.38 \\
\hline Orthogonal fractional experimental design & 0.25 & 1.00 & 0.50 \\
\hline $\begin{array}{l}\text { Utility-balanced fractional experimental } \\
\text { design }\end{array}$ & 0.08 & 0.33 & 0.33 \\
\hline Random Fractional Experimental Design & 0.17 & 0.67 & 0.42 \\
\hline
\end{tabular}

\begin{tabular}{|c|c|c|c|}
\hline \multicolumn{4}{|c|}{ Experimentally observed fraction of second-best votes for the status quo } \\
\hline Observed: Orthogonal experimental results & 0.03 & 1.00 & 0.40 \\
\hline (Robust standard error) & $(0.04)$ & $(\mathrm{N} / \mathrm{A})$ & $(0.15)$ \\
\hline Observed: Utility-balanced experimental & 0.04 & 0.07 & 0.47 \\
\hline results & $(0.03)$ & $(0.03)$ & $(0.18)$ \\
\hline (Robust standard error) & & & \\
\hline Observed: Random experimental results & 0.02 & 0.80 & 0.39 \\
\hline (Robust standard error) & $(0.02)$ & $(0.16)$ & $(0.10)$ \\
\hline
\end{tabular}

Table 7. Predicted and observed votes for second-best options that are the status quo option 


\begin{tabular}{|r|c|c|c|}
\hline & Mean & Robust std. error & $95 \%$ Conf. int. \\
\hline By method to create fractional factorial choice experiments & {$[0.90,0.95]$} \\
\hline Orthogonal & 0.93 & 0.015 & {$[0.83,0.91]$} \\
\hline Utility-balanced & 0.87 & 0.019 & {$[0.86,0.93]$} \\
\hline Random & 0.90 & 0.019 & {$[0.81,0.90]$} \\
\hline By fraction of choice options preferred to the status quo $(\pi)$ & 0.024 & {$[0.89,0.95]$} \\
\hline$\pi=0.125$ & 0.85 & 0.015 & {$[0.89,0.95]$} \\
\hline
\end{tabular}

Table 8. Rates of demand revelation 


\begin{tabular}{|r|c|c|c|}
\hline \multicolumn{4}{|c|}{ By method to create fractional factorial choice experiments } \\
\hline Orthogonal & 0.89 & 0.037 & {$[0.81,0.96]$} \\
\hline Utility-balanced & 0.95 & 0.026 & {$[0.90,1.00]$} \\
\hline Random & 0.93 & 0.027 & {$[0.87,0.98]$} \\
\hline$\pi=0.125$ & 0.99 & 0.003 & {$[0.99,1.00]$} \\
\hline$\pi=0.50$ & 0.84 & 0.048 & {$[0.75,0.94]$} \\
\hline$\pi=0.75$ & 0.56 & 0.079 & {$[0.41,0.72]$} \\
\hline
\end{tabular}

Table 9. Fraction of status quo votes that are demand revealing 
Sample choice task for quality-differentiated beef steaks (Lusk and Schroeder 2004, p. 469). ${ }^{\text {a }}$

\begin{tabular}{|c|c|c|c|c|c|c|}
\hline \multirow{5}{*}{$\begin{array}{c}\text { Scenario } \\
11\end{array}$} & \multicolumn{5}{|c|}{ Steaks } & \multirow{3}{*}{$\begin{array}{l}\text { None of } \\
\text { These }\end{array}$} \\
\hline & & iuarante & & USDA & Certified & \\
\hline & Generic & Tender & Natural & Choice & Angus Beef & \\
\hline & $\$ 6.75$ & $\$ 7.88$ & $\$ 9.00$ & $\$ 5.63$ & $\$ 7.88$ & \\
\hline & R & R & $\Omega$ & R & ת & $\Omega$ \\
\hline I would choose ... & $\square$ & $\square$ & $\square$ & $\square$ & $\square$ & $\square$ \\
\hline
\end{tabular}

Sample choice task for use of public land for endangered spedies protection versus military training (Smith and McKee 2007, p. 232). ${ }^{\text {b }}$

Question 5

Suppose the following three options were the only options available for managing the balance between endangered species encroachment and the DOD training mission. mission. Please indicate which option you prefer by placing an " $X$ " in one of the boxes below.

\begin{tabular}{|lccc|}
\hline Feature & Option A & Option B & $\begin{array}{c}\text { Option C: } \\
\text { Current Status }\end{array}$ \\
Payment per household & $\$ 50$ & $\$ 75$ & None \\
Impact on species survival & High & Medium & Low \\
Impact on soldiersí readiness & Medium & Low & High \\
\hline
\end{tabular}

I would choose A

I would choose B

I would choose $\mathrm{C}$

Sample choice task for a cervical cancer screening program (Ryan and Wordsworth 2000, p. 511). ${ }^{\mathrm{c}}$

- Choice 1

\begin{tabular}{|l|c|c|}
\hline Time between smears (years) & 3 & 1 \\
\hline Time for results (days) & 28 & 10 \\
\hline Chance of being recalled & $11 \%$ & $20 \%$ \\
\hline Chance of abnonnality & $10 \%$ & $10 \%$ \\
\hline Chance of dying from cervical cancer & $2 \%$ & $0.8 \%$ \\
\hline Cost of each smear $(£)$ & 5 & 20 \\
\hline \multicolumn{1}{|c|}{ Prefer } & Option & Prefer Option B \\
\hline
\end{tabular}

Which Option would you prefer? (tick one box only)

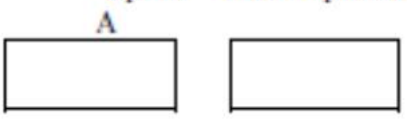

Prefer no

screening

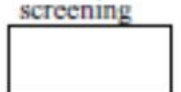

aLusk, J. \& Schroeder, T. (2004). Are choice experiments incentive compatible? A test with quality-differentiated beef steaks. American Journal of Agricultural Economics, 86(2), 467-482. By permission of Oxford University Press. 'S Smith, J. \& McKee, M. (2007). 'People or prairie chickens' revisited: stated preferences with explicit nonmarket trade-offs. Defence and Peace Economics, 18(3), 233-244. Taylor \& Francis Ltd. Reprinted by permission of the publisher. 'Ryan, M. \& Wordsworth, S. (2000). Sensitivity of willingness to pay estimate to the level of attributes in discrete choice experiments. Scottish Journal of Political Economy, 47(5), 504-524. (C) Scottish

Economic Society 2000. John Wiley \& Sons. Reprinted with permission of the publisher.

Figure 1. Sample choice tasks from choice experiment surveys (Lusk and Schroeder 2004, Smith and McKee 2007, Ryan and Wordsworth 2000) 
Your value of $A$ is: 3

Your value of $B$ is: 7

$\begin{array}{lll}\frac{\text { Option 1 }}{1 \text { unit of A }} & \text { Option 2 } & \text { Option 3 (current portfolio) } \\ \begin{array}{ll}\text { 3 units of B } \\ \text { Cost }=5\end{array} & 1 \text { units of } \text { A } & \text { B unit of A } \\ \text { Cost }=10 & 1 \text { unit of B } \\ & & \text { Cost }=0\end{array}$

Please select which option you wish to vote for below:

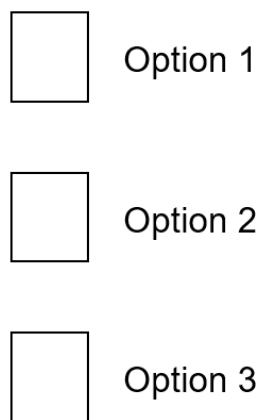

Figure 2. Sample experimental ballot 


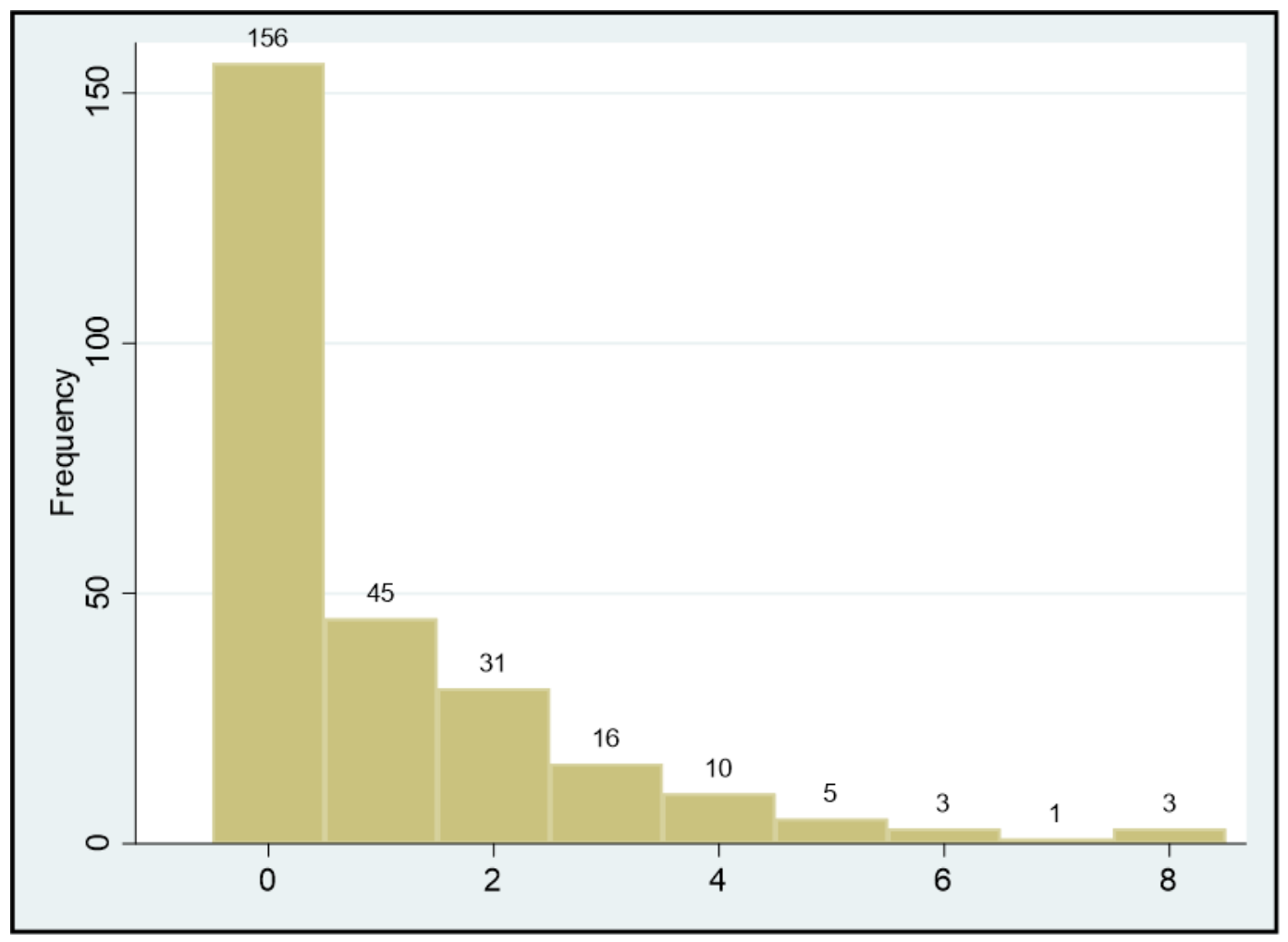

Figure 3. Frequency of number of second-best votes per subject 


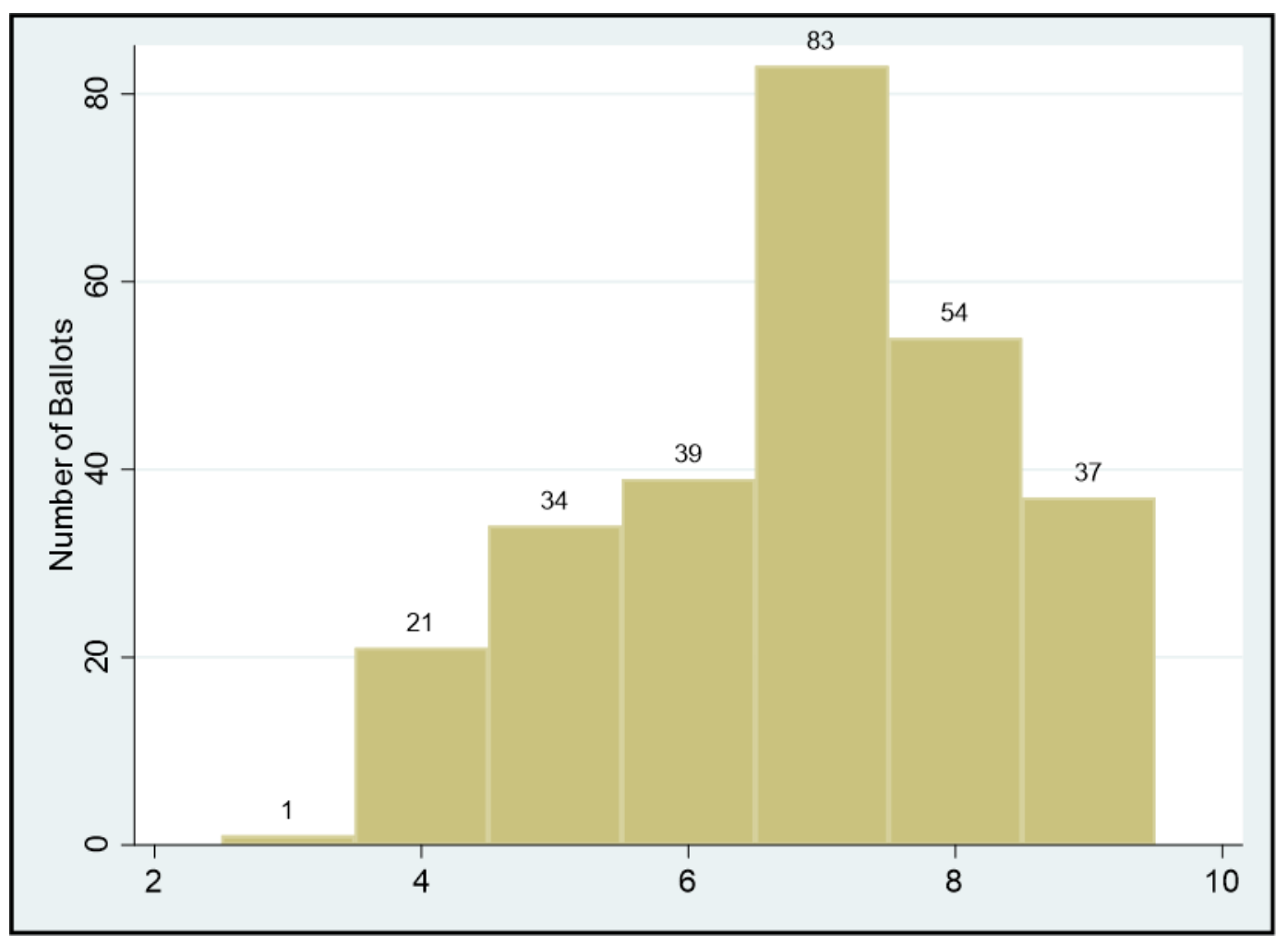

Figure 4. Ranking (out of 9) of the worst option in a choice set when a non-demand revealing vote for the second-best option was cast 


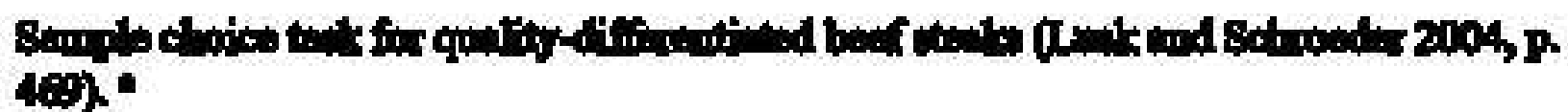

\begin{tabular}{|c|c|c|c|c|c|c|}
\hline \multirow{5}{*}{$\begin{array}{c}\text { Scenario } \\
11\end{array}$} & \multicolumn{5}{|c|}{ Steaks } & \multirow{3}{*}{$\begin{array}{c}\text { None of } \\
\text { These }\end{array}$} \\
\hline & \multicolumn{3}{|c|}{ Guaranteed } & ESDA & Certified & \\
\hline & Generic & Tender & Natural & Choice & Angus Beef & \\
\hline & $\$ 6.75$ & 57.88 & 59.00 & $\$ 5.63$ & $\$ 7.88$ & \\
\hline & $\mathbb{L}$ & $\Omega$ & 1 & $\Omega$ & $\mathbb{2}$ & 具 \\
\hline I would choose & $\square$ & $\square$ & $\square$ & $\square$ & $\square$ & $\square$ \\
\hline
\end{tabular}

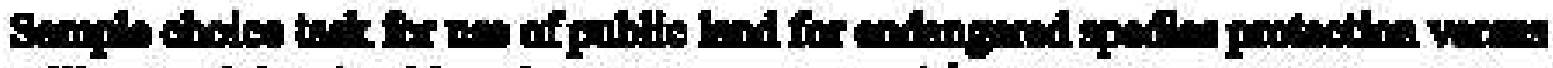

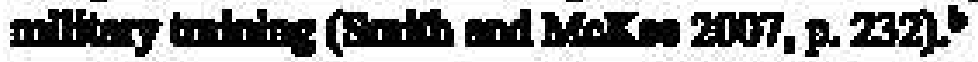 \\ Question 5}

Suppose the following three options were the only options available for managing the balance between endangered species encroachment and the DOD training mission. mission. Please indicate which option you prefer by placing an " $X$ " in one of the boxes below.

\begin{tabular}{|c|c|c|c|}
\hline Feature & Option A & Option B & $\begin{array}{c}\text { Option C: } \\
\text { Current Status }\end{array}$ \\
\hline & $\$ 5$ & $\$ 75$ & None \\
\hline Impact on species survival & High & Medium & Low \\
\hline Impact on soldiersi readiness & Medium & Low & High \\
\hline
\end{tabular}

$\square$

I would choose $\mathrm{A}$

I would choose B

I would choose $\mathrm{C}$

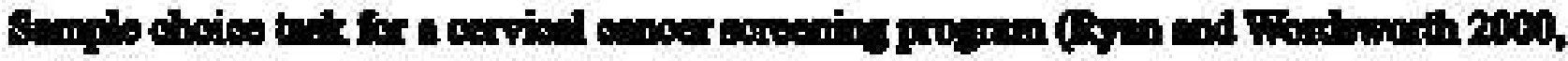 p. 511)*}

- Choice 1

\begin{tabular}{|l|c|c|}
\hline Time between smears (years) & 3 & 1 \\
\hline Time for results (days) & 28 & 10 \\
\hline Chance of being recalled & $11 \%$ & $20 \%$ \\
\hline Chance of abnormality & $10 \%$ & $10 \%$ \\
\hline Chance of dying from cervical cancer & $2 \%$ & $0.8 \%$ \\
\hline Cost of each smear $(€)$ & 5 & 20 \\
\hline
\end{tabular}

Prefer

Option

Prefer Option B

Prefer no

Which Option would you prefer? (tick one bax onty)

A

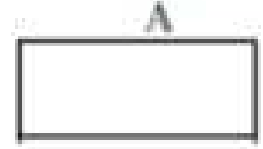

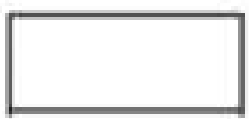

screcning

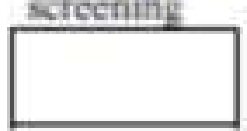




\section{Option 1}
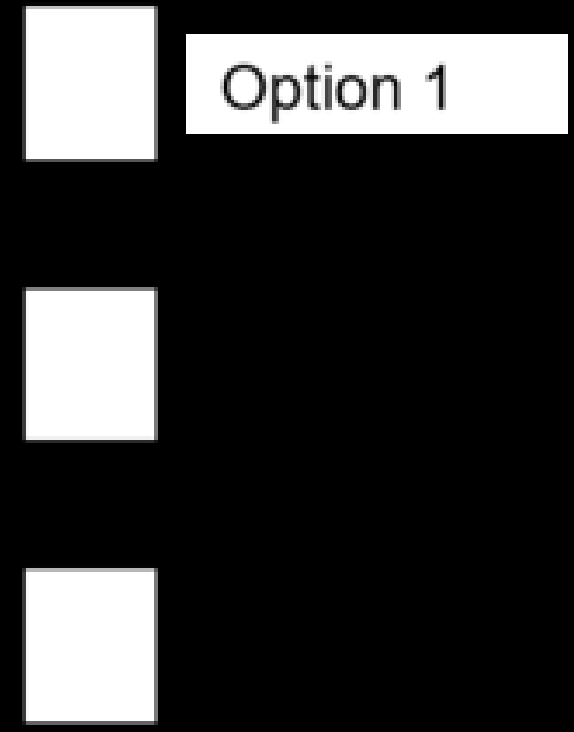


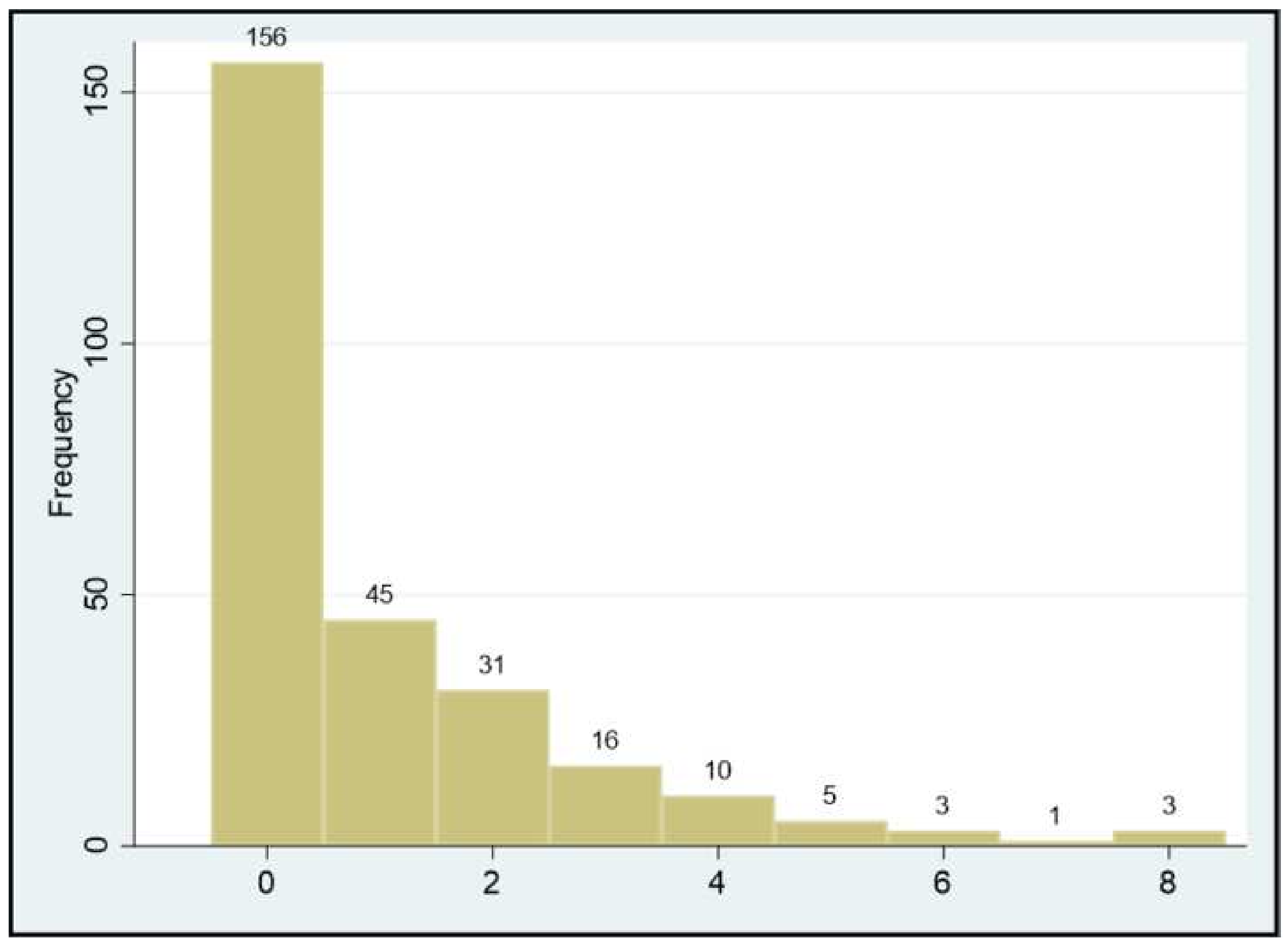


Click here to access/download;Figure;PublicChoice_Figure4Image.tif $\underline{\underline{\Perp}}$

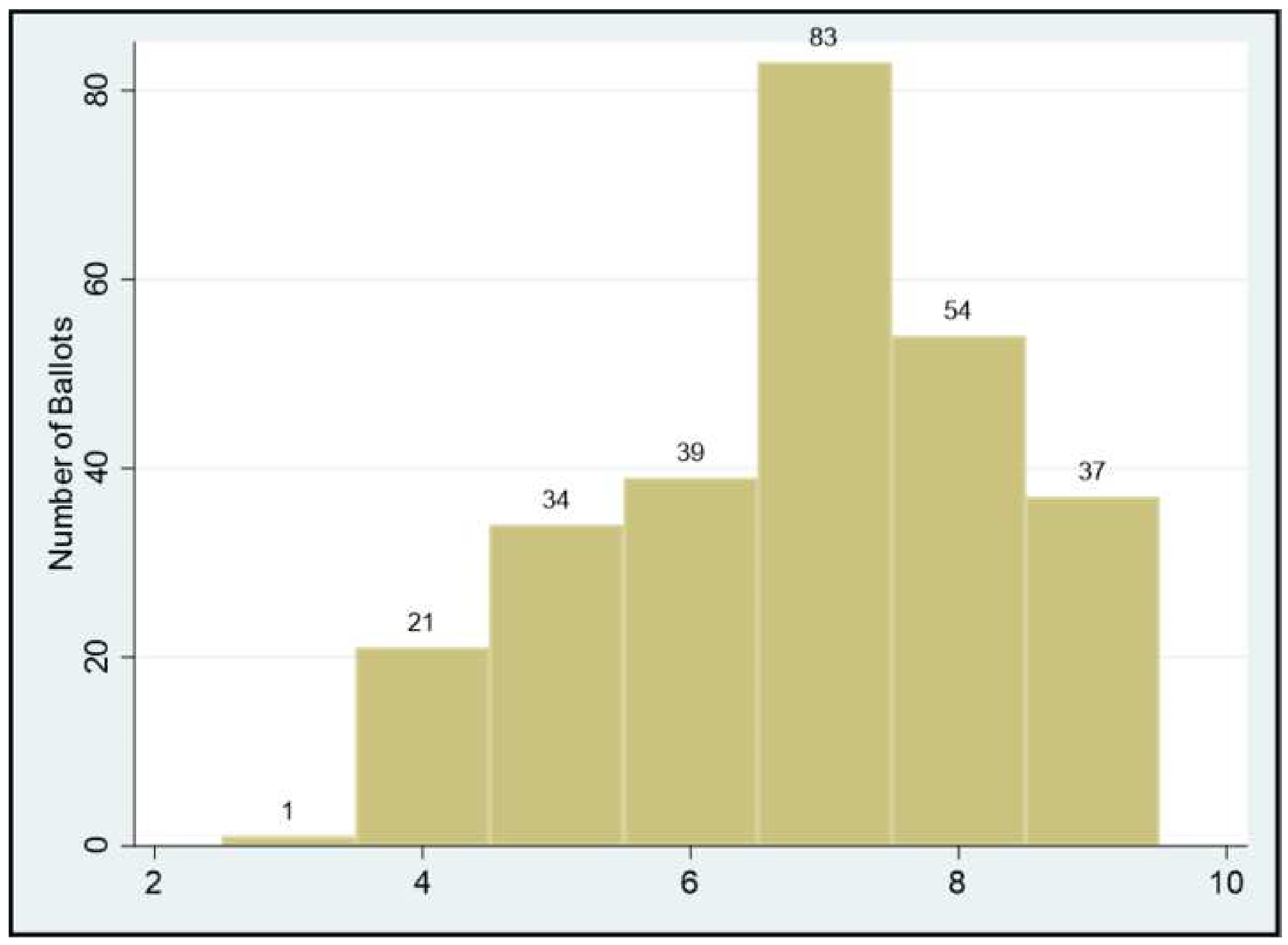

83 
Reprint Rights - Lusk and Schroeder Figure 9/25/2019

Click here to view linked References
Click here to access/download;Attachment to

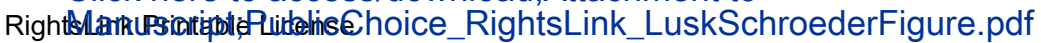

\section{OXFORD UNIVERSITY PRESS LICENSE TERMS AND CONDITIONS}

Sep 25, 2019

This Agreement between Dr. Katherine Silz-Carson ("You") and Oxford University Press ("Oxford University Press") consists of your license details and the terms and conditions provided by Oxford University Press and Copyright Clearance Center.

\section{All payments must be made in full to CCC. For payment instructions, please see information listed at the bottom of this form.}

License Number

License date

Licensed Content Publisher

Licensed Content Publication

Licensed Content Title

Licensed Content Author

Licensed Content Date

Licensed Content Volume

Licensed Content Issue

Type of Use

Requestor type

Pharmaceutical support or sponsorship for this project

Format

Portion

Number of figures/tables

Will you be translating?

Circulation/distribution

Title of new article

Lead author

Title of targeted journal

Publisher

Expected publication date

Portions

Requestor Location
4676180739576

Sep 25, 2019

Oxford University Press

American Journal of Agricultural Economics

Are Choice Experiments Incentive Compatible? A Test with Quality Differentiated Beef Steaks

Lusk, Jayson L.; Schroeder, Ted C.

May 1, 2004

86

2

Journal

Educational Institution/Non-commercial/ Not for-profit

No

Print and electronic

Figure/table

1

No

50000

Public resource allocation, strategic behavior and status quo bias in choice experiments

Katherine Silz-Carson

Public Choice

Springer

Jun 2020

Figure 1, page 469

Dr. Katherine Silz-Carson

2086 Brookwood Drive

COLORADO SPRINGS, CO 80918

United States

Attn: Dr. Katherine Silz-Carson

Publisher Tax ID

GB125506730

Billing Type

Credit Card 
Credit card info

Credit card expiration

Total
Visa ending in 8313

$03 / 2020$

96.00 USD

Terms and Conditions

\section{STANDARD TERMS AND CONDITIONS FOR REPRODUCTION OF MATERIAL FROM AN OXFORD UNIVERSITY PRESS JOURNAL}

1. Use of the material is restricted to the type of use specified in your order details.

2. This permission covers the use of the material in the English language in the following territory: world. If you have requested additional permission to translate this material, the terms and conditions of this reuse will be set out in clause 12 .

3. This permission is limited to the particular use authorized in (1) above and does not allow you to sanction its use elsewhere in any other format other than specified above, nor does it apply to quotations, images, artistic works etc that have been reproduced from other sources which may be part of the material to be used.

4. No alteration, omission or addition is made to the material without our written consent. Permission must be re-cleared with Oxford University Press if/when you decide to reprint. 5. The following credit line appears wherever the material is used: author, title, journal, year, volume, issue number, pagination, by permission of Oxford University Press or the sponsoring society if the journal is a society journal. Where a journal is being published on behalf of a learned society, the details of that society must be included in the credit line. 6. For the reproduction of a full article from an Oxford University Press journal for whatever purpose, the corresponding author of the material concerned should be informed of the proposed use. Contact details for the corresponding authors of all Oxford University Press journal contact can be found alongside either the abstract or full text of the article concerned, accessible from www.oxfordjournals.org Should there be a problem clearing these rights, please contact journals.permissions@oup.com

7. If the credit line or acknowledgement in our publication indicates that any of the figures, images or photos was reproduced, drawn or modified from an earlier source it will be necessary for you to clear this permission with the original publisher as well. If this permission has not been obtained, please note that this material cannot be included in your publication/photocopies.

8. While you may exercise the rights licensed immediately upon issuance of the license at the end of the licensing process for the transaction, provided that you have disclosed complete and accurate details of your proposed use, no license is finally effective unless and until full payment is received from you (either by Oxford University Press or by Copyright Clearance Center (CCC)) as provided in CCC's Billing and Payment terms and conditions. If full payment is not received on a timely basis, then any license preliminarily granted shall be deemed automatically revoked and shall be void as if never granted. Further, in the event that you breach any of these terms and conditions or any of CCC's Billing and Payment terms and conditions, the license is automatically revoked and shall be void as if never granted. Use of materials as described in a revoked license, as well as any use of the materials beyond the scope of an unrevoked license, may constitute copyright infringement and Oxford University Press reserves the right to take any and all action to protect its copyright in the materials.

9. This license is personal to you and may not be sublicensed, assigned or transferred by you to any other person without Oxford University Press's written permission.

10. Oxford University Press reserves all rights not specifically granted in the combination of (i) the license details provided by you and accepted in the course of this licensing transaction, (ii) these terms and conditions and (iii) CCC's Billing and Payment terms and conditions. 
11. You hereby indemnify and agree to hold harmless Oxford University Press and CCC, and their respective officers, directors, employs and agents, from and against any and all claims arising out of your use of the licensed material other than as specifically authorized pursuant to this license.

12. Other Terms and Conditions:

v1.4

Questions? customercare@copyright.com or +1-855-239-3415 (toll free in the US) or +1-978-646-2777. 
Reprint Rights - Smith and McKee Figure

9/26/2019

Click here to view linked References
Click here to access/download;Attachment to

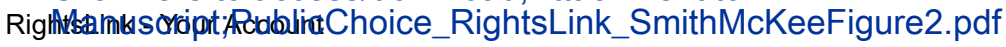

\section{TAYLOR \& FRANCIS LICENSE TERMS AND CONDITIONS}

Sep 26, 2019

This Agreement between Dr. Katherine Silz-Carson ("You") and Taylor \& Francis ("Taylor \& Francis") consists of your license details and the terms and conditions provided by Taylor \& Francis and Copyright Clearance Center.

The publisher has provided special terms related to this request that can be found at the end of the Publisher's Terms and Conditions.

\section{All payments must be made in full to CCC. For payment instructions, please see information listed at the bottom of this form.}

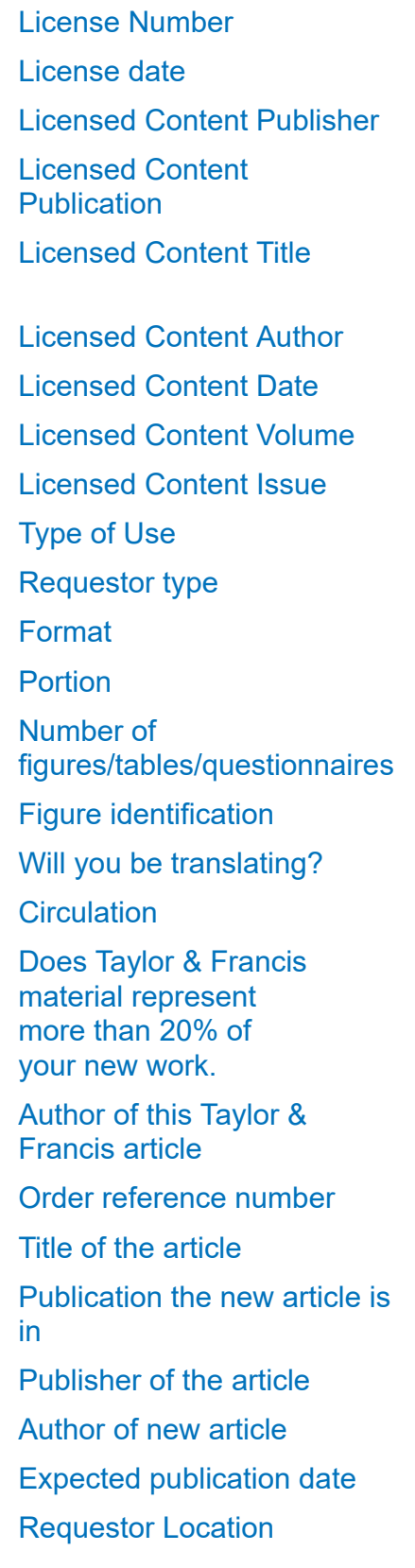

4676690290507

Sep 26, 2019

Taylor \& Francis

Defence and Peace Economics

'PEOPLE OR PRAIRIE CHICKENS' REVISITED: STATED PREFERENCES WITH EXPLICIT NONMARKET TRADE-OFFS

Jeffrey S. Smith, , Michael McKee

Jun 1, 2007

18

3

Journal/Magazine

academic/educational

print and electronic

Figure/table/questionnaire

1

Figure 2, page 232

no

500000

no

no

Public resource allocation, strategic behavior and status quo bias in choice experiments

Public Choice

Springer

Katherine Silz-Carson

Jun 2020

Dr. Katherine Silz-Carson

2086 Brookwood Drive

COLORADO SPRINGS, CO 80918 


\section{United States \\ Attn: Dr. Katherine Silz-Carson \\ Billing Type \\ Credit card info \\ Credit card expiration \\ Total \\ Terms and Conditions \\ Credit Card \\ Visa ending in 8313 \\ $03 / 2020$ \\ 165.00 USD \\ COPYRIGHT LICENSE TERMS AND CONDITIONS (PERMISSIONS)}

1. Informa UK Ltd, trading as Taylor \& Francis Group, of 5 Howick Place, London SW1P 1WG ("Us, We, Our") hereby offer you permission to use the licensed products or content (the "Product(s)") as set out in the details of use you specified during the order process and are found in the order details above and always subject to and in accordance with these terms and conditions (the "Terms").

2. This permission does not cover any third party copyrighted work which may appear in the material for which the permission is requested.

3. Full acknowledgement must be included showing article title, author, full Journal title, date of publication and publisher, reprinted by permission of the publisher (Taylor \& Francis Ltd, http://www.tandfonline.com ).

4. All reasonable efforts must be made to contact the author(s) to notify them of your intentions and confirm they are happy with the permission being granted.

5. No alterations may be made to our work without written consent.

6. Permission is valid only when payment has been received by the Copyright Clearance Center.

7. Permission is granted by Copyright Clearance Center Inc (CCC) on Taylor and Francis's behalf and by agreeing to the terms and conditions listed above you also agree to (CCC's) additional terms and conditions as the administrators of this licensing service, these terms and conditions are agreed to as a condition of establishing an account and may be seen at any time at http://myaccount.copyright.com.

8. This license is granted strictly according to the details of use you specified during the order process and are found in the order details above.

9. In addition, the following terms apply to the particular use specified below:

\section{a. Additional Terms and Conditions for Reuse in a Book/Textbook, Journal/Magazine,Promotional Materials/Pamphlet/Brochure, Newspaper and Newsletter}

i. Permission is granted for a fee for non-exclusive world rights for one edition only. Use beyond this edition requires obtaining another license. This license is granted strictly according to the details of use you specified during the order process and are found in the order details above.

ii. Unless otherwise stated, entire article electronic reuse is excluded with the exception of eBooks.

iii. This license does not cover usage in a Custom Publishing Products and or database. This license does not cover individual chapter sales.

iv. This license does not cover cases in which Taylor and Francis material consists of more than $20 \%$ of your new work.

v. The following terms only apply to signatories of the International Association of Scientific, Technical and Medical (STM) Publishers guidelines. http://www.stm-assoc.org/about-stm. Taylor and Francis adhere to STM guidelines, providing some reuse licenses for free as specified in the guidelines. We are pleased to grant you non-exclusive world rights in English and in all languages, in print and electronic editions of this Work in its first and future editions and revisions, on the following conditions:

The original source of publication and Taylor \& Francis Ltd., are acknowledged in the caption, including a reference to the Journal's web site: Taylor \& Francis Ltd, http://www.tandfonline.com

You do not license to any third-party permission to reproduce this copyrighted material, in any form, and at any time.

b. Additional Terms and Conditions to reproduce a T\&F title in a T\&F imprint 
i. Permission is granted without charge for non-exclusive world for one edition only. Use beyond this edition requires obtaining another license.

ii. Your use is limited to use within an Taylor \& Francis title.

\section{c. Additional Terms and Conditions to Post on a Website}

i. Permission is granted for a fee for non-exclusive world rights for this usage only. Permission must therefore be obtained for any further use.

ii. For text extracts permission is limited to a maximum of 500 words or 1 page. Taylor and Francis do not allow full articles to appear on third party web sites.

\section{d. Additional Terms and Conditions to reuse in Library Reserve/e-Reserve}

i. Permission is granted for a fee to reproduce the entire article for use by an educational institution.

ii. Use in an Electronic Reserve must be password protected

\section{e. Additional Terms and Conditions to reuse in a Course pack/Classroom Materials}

i. Permission is limited to non-exclusive world rights.

ii. Electronic course packs must be used on a secure website.

iii. Permission is granted for a period of 12 months from date the course commences.

\section{f. Additional Terms and Conditions for Corporate Permissions Requests}

i. Permission is granted for a fee for non-exclusive world rights for this usage only. Permission must therefore be obtained for any further use.

ii. Corporate requests are defined as requests with the following requestor types in the order details of the license: pharmaceutical, biotech, or medical device company; agency acting on behalf of a pharma company; commercial/for-profit

iii. Permission is granted for a period of 12 months from the license date ("Term").

iv. The Products shall not be used in any manner that may be considered by Us (acting in Our sole discretion) as derogatory to the title, content and/or authors of the Products

v. You warrant that the Products shall not be used in any manner which may limit Our ability and/or that of its owners, successors or assignees to exploit the Products in any way whether for financial gain or any other benefit.

vi. Upon expiration of the Term for any reason whatsoever, you agree to immediately cease using the Products and permanently delete and remove the Products from your works, systems and any publication, system or database.

vii. You hereby confirm that neither Us, nor any of Our group companies nor Our or their respective officers, employees and/or agents will be responsible for any liability, costs, damages or expenses incurred by you or any third party in connection with your use of the Products.

viii. The rights granted to you under these Terms may be revoked by Us at any time if you breach any of the Terms or if We, acting in Our reasonable discretion, have reasonable grounds to believe that you may breach any of the Terms. Following any such revocation, your rights to use the Products shall immediately cease and you shall have no further rights in respect of the Products.

These Terms shall be governed by and construed in accordance with English law and both parties shall submit to the exclusive jurisdiction of the courts of England in respect of any dispute arising out of or in connection with these Terms or the Products. Other Conditions: None

Version 1.10

Questions? customercare@copyright.com or +1-855-239-3415 (toll free in the US) or +1-978-646-2777. 


\section{JOHN WILEY AND SONS LICENSE TERMS AND CONDITIONS}

Sep 25, 2019

This Agreement between Dr. Katherine Silz-Carson ("You") and John Wiley and Sons ("John Wiley and Sons") consists of your license details and the terms and conditions provided by John Wiley and Sons and Copyright Clearance Center.
License Number
4676180560231
License date
Sep 25, 2019
Licensed Content Publisher
John Wiley and Sons
Licensed Content Publication
Licensed Content Title
Licensed Content Author
Licensed Content Date
Nov 1, 2001
Licensed Content Pages
10
Type of use
Journal/Magazine
Requestor type
University/Academic

Sensitivity of Willingness to Pay Estimates to the Level of Attributes in Discrete Choice Experiments

Mandy Ryan,Sarah Wordsworth

Is the reuse sponsored by or no associated with a pharmaceutical or medical products company?

Format

Print and electronic

Portion Figure/table

Number of figures/tables

1

Original Wiley figure/table

Figure 1, page 511

number(s)

Will you be translating?

No

Circulation

50000 or greater

Title of new article

Public resource allocation, strategic behavior and status quo bias in choice experiments

Publication the new article is Public Choice

in

Publisher of new article Springer

Author of new article Katherine Silz-Carson

Expected publication date of Jun 2020

new article

Estimated size of new article 25

(pages)

Requestor Location

Dr. Katherine Silz-Carson

2086 Brookwood Drive 
United States

Attn: Dr. Katherine Silz-Carson

Publisher Tax ID

Total

Terms and Conditions
EU826007151

0.00 USD

\section{TERMS AND CONDITIONS}

This copyrighted material is owned by or exclusively licensed to John Wiley \& Sons, Inc. or one of its group companies (each a"Wiley Company") or handled on behalf of a society with which a Wiley Company has exclusive publishing rights in relation to a particular work (collectively "WILEY"). By clicking "accept" in connection with completing this licensing transaction, you agree that the following terms and conditions apply to this transaction (along with the billing and payment terms and conditions established by the Copyright Clearance Center Inc., ("CCC's Billing and Payment terms and conditions"), at the time that you opened your RightsLink account (these are available at any time at http://myaccount.copyright.com).

\section{Terms and Conditions}

- The materials you have requested permission to reproduce or reuse (the "Wiley Materials") are protected by copyright.

- You are hereby granted a personal, non-exclusive, non-sub licensable (on a standalone basis), non-transferable, worldwide, limited license to reproduce the Wiley. Materials for the purpose specified in the licensing process. This license, and any CONTENT (PDF or image file) purchased as part of your order, is for a one-time use only and limited to any maximum distribution number specified in the license. The first instance of republication or reuse granted by this license must be completed within two years of the date of the grant of this license (although copies prepared before the end date may be distributed thereafter). The Wiley Materials shall not be used in any other manner or for any other purpose, beyond what is granted in the license. Permission is granted subject to an appropriate acknowledgement given to the author, title of the material/book/journal and the publisher. You shall also duplicate the copyright notice that appears in the Wiley publication in your use of the Wiley Material. Permission is also granted on the understanding that nowhere in the text is a previously published source acknowledged for all or part of this Wiley Material. Any third party content is expressly excluded from this permission.

- With respect to the Wiley Materials, all rights are reserved. Except as expressly granted by the terms of the license, no part of the Wiley Materials may be copied, modified, adapted (except for minor reformatting required by the new Publication), translated, reproduced, transferred or distributed, in any form or by any means, and no derivative works may be made based on the Wiley Materials without the prior permission of the respective copyright owner.For STM Signatory Publishers clearing permission under the terms of the STM Permissions Guidelines only, the terms of the license are extended to include subsequent editions and for editions in other languages, provided such editions are for the work as a whole in situ and does not involve the separate exploitation of the permitted figures or extracts, You may not alter, remove or suppress in any manner any copyright, trademark or other notices displayed by the Wiley Materials. You may not license, rent, sell, loan, lease, pledge, offer as security, transfer or assign the Wiley Materials on a stand-alone basis, or any of the rights granted to you hereunder to any other person. 
- The Wiley Materials and all of the intellectual property rights therein shall at all times remain the exclusive property of John Wiley \& Sons Inc, the Wiley Companies, or their respective licensors, and your interest therein is only that of having possession of and the right to reproduce the Wiley Materials pursuant to Section 2 herein during the continuance of this Agreement. You agree that you own no right, title or interest in or to the Wiley Materials or any of the intellectual property rights therein. You shall have no rights hereunder other than the license as provided for above in Section 2. No right, license or interest to any trademark, trade name, service mark or other branding ("Marks") of WILEY or its licensors is granted hereunder, and you agree that you shall not assert any such right, license or interest with respect thereto

- NEITHER WILEY NOR ITS LICENSORS MAKES ANY WARRANTY OR REPRESENTATION OF ANY KIND TO YOU OR ANY THIRD PARTY, EXPRESS, IMPLIED OR STATUTORY, WITH RESPECT TO THE MATERIALS OR THE ACCURACY OF ANY INFORMATION CONTAINED IN THE MATERIALS, INCLUDING, WITHOUT LIMITATION, ANY IMPLIED WARRANTY OF MERCHANTABILITY, ACCURACY, SATISFACTORY QUALITY, FITNESS FOR A PARTICULAR PURPOSE, USABILITY, INTEGRATION OR NON-INFRINGEMENT AND ALL SUCH WARRANTIES ARE HEREBY EXCLUDED BY WILEY AND ITS LICENSORS AND WAIVED BY YOU.

- WILEY shall have the right to terminate this Agreement immediately upon breach of this Agreement by you.

- You shall indemnify, defend and hold harmless WILEY, its Licensors and their respective directors, officers, agents and employees, from and against any actual or threatened claims, demands, causes of action or proceedings arising from any breach of this Agreement by you.

- IN NO EVENT SHALL WILEY OR ITS LICENSORS BE LIABLE TO YOU OR ANY OTHER PARTY OR ANY OTHER PERSON OR ENTITY FOR ANY SPECIAL, CONSEQUENTIAL, INCIDENTAL, INDIRECT, EXEMPLARY OR PUNITIVE DAMAGES, HOWEVER CAUSED, ARISING OUT OF OR IN CONNECTION WITH THE DOWNLOADING, PROVISIONING, VIEWING OR USE OF THE MATERIALS REGARDLESS OF THE FORM OF ACTION, WHETHER FOR BREACH OF CONTRACT, BREACH OF WARRANTY, TORT, NEGLIGENCE, INFRINGEMENT OR OTHERWISE (INCLUDING, WITHOUT LIMITATION, DAMAGES BASED ON LOSS OF PROFITS, DATA, FILES, USE, BUSINESS OPPORTUNITY OR CLAIMS OF THIRD PARTIES), AND WHETHER OR NOT THE PARTY HAS BEEN ADVISED OF THE POSSIBILITY OF SUCH DAMAGES. THIS LIMITATION SHALL APPLY NOTWITHSTANDING ANY FAILURE OF ESSENTIAL PURPOSE OF ANY LIMITED REMEDY PROVIDED HEREIN.

- Should any provision of this Agreement be held by a court of competent jurisdiction to be illegal, invalid, or unenforceable, that provision shall be deemed amended to achieve as nearly as possible the same economic effect as the original provision, and the legality, validity and enforceability of the remaining provisions of this Agreement shall not be affected or impaired thereby.

- The failure of either party to enforce any term or condition of this Agreement shall not constitute a waiver of either party's right to enforce each and every term and condition of this Agreement. No breach under this agreement shall be deemed waived or 
excused by either party unless such waiver or consent is in writing signed by the party granting such waiver or consent. The waiver by or consent of a party to a breach of any provision of this Agreement shall not operate or be construed as a waiver of or consent to any other or subsequent breach by such other party.

- This Agreement may not be assigned (including by operation of law or otherwise) by you without WILEY's prior written consent.

- Any fee required for this permission shall be non-refundable after thirty (30) days from receipt by the $\mathrm{CCC}$.

- These terms and conditions together with CCC's Billing and Payment terms and conditions (which are incorporated herein) form the entire agreement between you and WILEY concerning this licensing transaction and (in the absence of fraud) supersedes all prior agreements and representations of the parties, oral or written. This Agreement may not be amended except in writing signed by both parties. This Agreement shall be binding upon and inure to the benefit of the parties' successors, legal representatives, and authorized assigns.

- In the event of any conflict between your obligations established by these terms and conditions and those established by CCC's Billing and Payment terms and conditions, these terms and conditions shall prevail.

- WILEY expressly reserves all rights not specifically granted in the combination of (i) the license details provided by you and accepted in the course of this licensing transaction, (ii) these terms and conditions and (iii) CCC's Billing and Payment terms and conditions.

- This Agreement will be void if the Type of Use, Format, Circulation, or Requestor Type was misrepresented during the licensing process.

- This Agreement shall be governed by and construed in accordance with the laws of the State of New York, USA, without regards to such state's conflict of law rules. Any legal action, suit or proceeding arising out of or relating to these Terms and Conditions or the breach thereof shall be instituted in a court of competent jurisdiction in New York County in the State of New York in the United States of America and each party hereby consents and submits to the personal jurisdiction of such court, waives any objection to venue in such court and consents to service of process by registered or certified mail, return receipt requested, at the last known address of such party.

\section{WILEY OPEN ACCESS TERMS AND CONDITIONS}

Wiley Publishes Open Access Articles in fully Open Access Journals and in Subscription journals offering Online Open. Although most of the fully Open Access journals publish open access articles under the terms of the Creative Commons Attribution (CC BY) License only, the subscription journals and a few of the Open Access Journals offer a choice of Creative Commons Licenses. The license type is clearly identified on the article.

\section{The Creative Commons Attribution License}

The Creative Commons Attribution License ( $\underline{\mathrm{CC}-\mathrm{BY}})$. allows users to copy, distribute and transmit an article, adapt the article and make commercial use of the article. The CC-BY license permits commercial and non-

\section{Creative Commons Attribution Non-Commercial License}

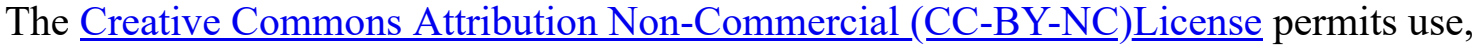
distribution and reproduction in any medium, provided the original work is properly cited 
and is not used for commercial purposes.(see below)

\section{Creative Commons Attribution-Non-Commercial-NoDerivs License}

The Creative Commons Attribution Non-Commercial-NoDerivs License (CC-BY-NC-ND) permits use, distribution and reproduction in any medium, provided the original work is properly cited, is not used for commercial purposes and no modifications or adaptations are made. (see below)

Use by commercial "for-profit" organizations

Use of Wiley Open Access articles for commercial, promotional, or marketing purposes requires further explicit permission from Wiley and will be subject to a fee.

Further details can be found on Wiley Online Library

http://olabout.wiley.com/WileyCDA/Section/id-410895.html

Other Terms and Conditions:

v1.10 Last updated September 2015

Questions? customercare@copyright.com or +1-855-239-3415 (toll free in the US) or +1-978-646-2777. 


\section{DEPARTMENT OF THE AIR FORCE THE DEPARTMENT OF ECONOMICS AND GEOSCIENCES USAF ACADEMY, COLORADO}

30 September 2019

William F. Shughart II

Editor-in-Chief

Public Choice

Dear Dr. Shughart:

Please find enclosed a revised version of our submission, Public Resource Allocation, Strategic Behavior, and Status Quo Bias in Choice Experiments (PUCH-D-19-00225R1) to Public Choice. In this revision, we have accepted all of the changes required in your response to our previous revision. In addition, please note that we have obtained reprint permission for all figures included in Figure 1. These permissions are attached. As per the guidance we received from you, all figures are attached as TIFF files.

Thank you for taking the time to provide such a detailed response to our revision. We look forward to seeing this paper appear in Public Choice.

Sincerely,

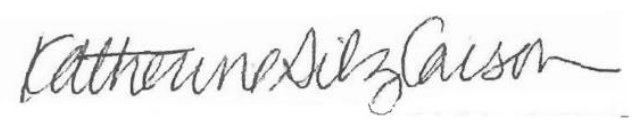

KATHERINE SILZ CARSON, Ph.D.

Professor of Economics 
Click here to access/download Supplementary Material SupplementalMaterials_Final.pdf 